\title{
NAPA wt Allele
}

National Cancer Institute

\section{Source}

National Cancer Institute. NAPA wt Allele. NCI Thesaurus. Code C126467.

Human NAPA wild-type allele is located in the vicinity of $19 q 13.33$ and is approximately 28 $\mathrm{kb}$ in length. This allele, which encodes alpha-soluble NSF attachment protein, plays a role in intracellular vesicle transport. 